\title{
Electron-topological, energetic and $\pi$-electron delocalization analysis of ketoenamine-enolimine tautomeric equilibrium
}

\author{
Agata Martyniak • Pawel Lipkowski • Noel Boens • \\ Aleksander Filarowski
}

Received: 5 December 2010 / Accepted: 28 March 2011/Published online: 27 April 2011

(C) The Author(s) 2011. This article is published with open access at Springerlink.com

\begin{abstract}
The ketoenamine-enolimine tautometic equilibrium has been studied by the analysis of aromaticity and electrontopological parameters. The influence of substituents on the energy of the transition state and of the tautomeric forms has been investigated for different positions of chelate chain. The quantum theory of atoms in molecules method (QTAIM) has been applied to study changes in the electron-topological parameters of the molecule with respect to the tautomeric equilibrium in intramolecular hydrogen bond. Dependencies of the HOMA aromaticity index and electron density at the critical points defining aromaticity and electronic state of the chelate chain on the transition state (TS), $\mathrm{OH}$ and $\mathrm{HN}$ tautomeric forms have been obtained.
\end{abstract}

Keywords Aromaticity - Carbonylamine - Enolimine · Intramolecular hydrogen bond - QTAIM - Tautomeric equilibrium · HOMA

\footnotetext{
A. Martyniak $\cdot$ A. Filarowski $(\square)$

Faculty of Chemistry, University of Wrocław,

14 F. Joliot-Curie str.,

50-383 Wrocław, Poland

e-mail: afil@ruc.dk

A. Filarowski

e-mail: afil@wchuwr.chem.uni.wroc.pl

P. Lipkowski

Theoretical Chemistry Group, Institute of Physical and

Theoretical Chemistry, Wrocław University of Technology,

Wyb. Wyspiańskiego 27,

50-370 Wrocław, Poland

N. Boens

Department of Chemistry, Katholieke Universiteit Leuven, Celestijnenlaan 200f - bus 02404,

3001 Leuven, Belgium
}

\section{Introduction}

The carbonylamines presented in the paper (Scheme 1) are prototypes of malonaldehydes investigated in a number of experimental and computational studies [1-3]. The given compounds can be referred to so-called resonance assisted hydrogen bond (RAHB) system being elaborated by Gilli et al. [4]. Recently the interest in RAHB has much grown due to the critics presented in refs $[5,6]$. It is noteworthy that the aryl Schiff bases were properly studied [7-9]. However, theoretical studies of the carbonylamine (alkyl derivatives of Schiff bases) are not as numerous [10-14]. Both the alkyl Schiff bases and the aryl Schiff bases (Scheme 1) contain a quasi-aromatic formation as a common feature. But, the experimental data [15-23] expose the principle difference between these two types of compounds. What makes them different is that the HN (ketoenamine) tautomeric form prevails for the alkyl derivatives [1026], meanwhile $\mathrm{OH}$ (enolimine) tautomeric form (Scheme 2) prevails for the aryl derivatives [7-9]. The transition from one form to another (the proton transfer) requires energetic expenditure $\left(\Delta \mathrm{E}_{\mathrm{PT}}\right)$. The change of tautomeric equilibrium is evoked by an acid-base balance and polarity of the environment. A series of papers [2740] deals with the ways the tautomeric equilibrium affects the aromatic state of a molecule with intramolecular hydrogen bonding.

To trace a change of a tautomeric equilibrium in carbonylamines experimentally is really challenging. It is also difficult to estimate the substituent influence in the chelate chain $(\mathrm{O}=\mathrm{C}-\mathrm{C}=\mathrm{C}-\mathrm{N})$ on the hydrogen bonding strength. This task is hampered by complementary phenomena (trans-cis isomerization [11] and $\mathrm{HO}-\mathrm{CH}=\mathrm{CH}-\mathrm{C}=$ $\mathrm{NR} \rightleftarrows \mathrm{O}=\mathrm{C}-\mathrm{CH}_{2}-\mathrm{CH}=\mathrm{NR}$ equilibrium [15-17]) observed experimentally for carbonylamines. However, quantum- 
<smiles></smiles>

Carbonylamine (Alkyl Schiff base)

Scheme 1 Alkyl and aryl Schiff bases

mechanical calculations make it possible to describe a complicated nature of hydrogen bond. This paper is concerned with the ketoenamine-enolimine tautomeric equilibrium (Scheme 2) and the calculations of the carbonylamines with various substituents $\left(\mathrm{CH}_{3}, \mathrm{H}, \mathrm{NH}_{2}\right.$, $\mathrm{Cl}$ and $\mathrm{F}$ ) in the chelate chain. The calculations were performed for the $\mathrm{OH}$ and $\mathrm{HN}$ tautomeric forms and transition state (Scheme 2) describing two main stages of the proton transfer process [41]. For description of these stages we calculated the difference of energies between them $\left(\Delta \mathrm{E}_{\mathrm{PT}}=\mathrm{E}_{\mathrm{OH}}-\mathrm{E}_{\mathrm{NH}}, \Delta \mathrm{E}_{\mathrm{TS}}=\mathrm{E}_{\mathrm{TS}}-\mathrm{E}_{\mathrm{HN}}\right.$; the energy of $\mathrm{HN}$ tautomer is taken as the ground energetic level) and the HOMA aromaticity index [42] and electron-topological parameters [43, 44]. HOMA index is a widely accepted parameter applied in the description of the aromaticity [45, 46]. The merit of HOMA index is in its ability to be used for the experimental [47] and computational [48] results. The difference of energies is one of the most reliable parameters in the description of the hydrogen bonding [49].

As for the HOMA aromaticity index, it has been repeatedly verified by the researchers of intramolecular hydrogen bonding during last decade [26, 27, 30-40]. There are papers dwelling on the influence of tautomeric equilibrium on the aromaticity of phenol, aniline and naphthol complexes [50]. This paper develops these studies with aim to unify the HOMA aromaticity index in the area of hydrogen bonding and electron-topological analysis.

\section{Computational details}

The calculations were performed with Gaussian 03 [51] sets of code using the $6-311+\mathrm{G}(\mathrm{d}, \mathrm{p})$ basis set [52-55] at the Møller-Plesset second-order perturbation level (MP2) [56]. QTAIM analysis was performed using the AIM2000 program [57] with all the default options.

The HOMA aromaticity index was calculated by the following formula:

$\mathrm{HOMA}=1-\frac{1}{n} \sum_{i=1}^{n} \alpha_{i}\left(R_{\text {opt }}-R_{i}\right)^{2}$

where $n$ is a number of bonds, $\alpha$ is an empirical constant, $\mathrm{R}_{\mathrm{opt}}$ and $\mathrm{R}_{\mathrm{i}}$ are the optimal and individual bond lengths taken from ref. 42. A higher HOMA aromaticity index corresponds to a more delocalized $\pi$-electronic system, hence a more aromatic formation [58].

\section{Results and discussion}

The influence of substituents on the intramolecular hydrogen bonding in the carbonylamines

The influence of substituents $\left(\mathrm{R}_{1}-\mathrm{R}_{3}\right)$ in the $\alpha, \beta$ and $\gamma$ positions on the ketoenamine-enolimine equilibrium can be described by the inductive constants [59] $\left(\sigma_{\mathrm{F}}=0, \sim 0,0.14\right.$, 0.44 and 0.45 for $\mathrm{H}, \mathrm{CH}_{3}, \mathrm{NH}_{2}, \mathrm{Cl}$ and $\mathrm{F}$, respectively). It is noteworthy, that the $\pi$-electron donation of $\mathrm{NH}_{2}$ group is small due to perpendicular orientation of its lone electron pair with respect to quasi-aromatic formation. This phenomenon was properly described by Sola et al. [60]. The increase of the electron acceptor ability of the $R_{1}$ and $R_{2}$ substituents (the increase of $\sigma_{\mathrm{F}}$ constant) in the $\alpha$ and $\beta$ positions results in the growth of both the energetic barrier of transition state $\left(\Delta \mathrm{E}_{\mathrm{TS}}\right)$ and the $\mathrm{OH}$ form $\left(\Delta \mathrm{E}_{\mathrm{PT}}\right)$, (Fig. 1a and b). This trend is traced for the $\mathrm{CH}_{3}$ (Fig. 1a) and $\mathrm{H}$ (Fig. 1b) substituents at the nitrogen atom, which serve as the basic ones for the predominant HN tautomeric form. An opposite picture is observed for the substituent $\left(\mathrm{R}_{3}\right)$ in the $\gamma$
Scheme 2 Where $\mathrm{R}_{1}, \mathrm{R}_{2}, \mathrm{R}_{3}$ and $\mathrm{R}_{4}$ are $\mathrm{CH}_{3}, \mathrm{H}, \mathrm{NH}_{2}, \mathrm{Cl}$ and F substituents<smiles>[R]C=CC</smiles>

$\mathrm{HN}$

FORM<smiles></smiles>

TS<smiles>[R]c1nc[n+]([R])c([R])c1[R]</smiles>

$\mathrm{OH}$ FORM 
Fig. 1 The energy levels of carbonylamine derivatives depending on substituents (black column respect to $\mathrm{R}_{1}=\mathrm{H}, \mathrm{CH}_{3}$, $\mathrm{NH}_{2}, \mathrm{Cl}, \mathrm{F} ; \mathrm{R}_{2}=\mathrm{R}_{3}=\mathrm{H}$; grey column respect to $\mathrm{R}_{2}=\mathrm{H}, \mathrm{CH}_{3}$, $\mathrm{NH}_{2}, \mathrm{Cl}, \mathrm{F} ; \mathrm{R}_{1}=\mathrm{R}_{3}=\mathrm{H}$; white column respect to $\mathrm{R}_{2}=\mathrm{H}, \mathrm{CH}_{3}$, $\mathrm{NH}_{2}, \mathrm{Cl}, \mathrm{F} ; \mathrm{R}_{1}=\mathrm{R}_{3}=\mathrm{H}$ ) a

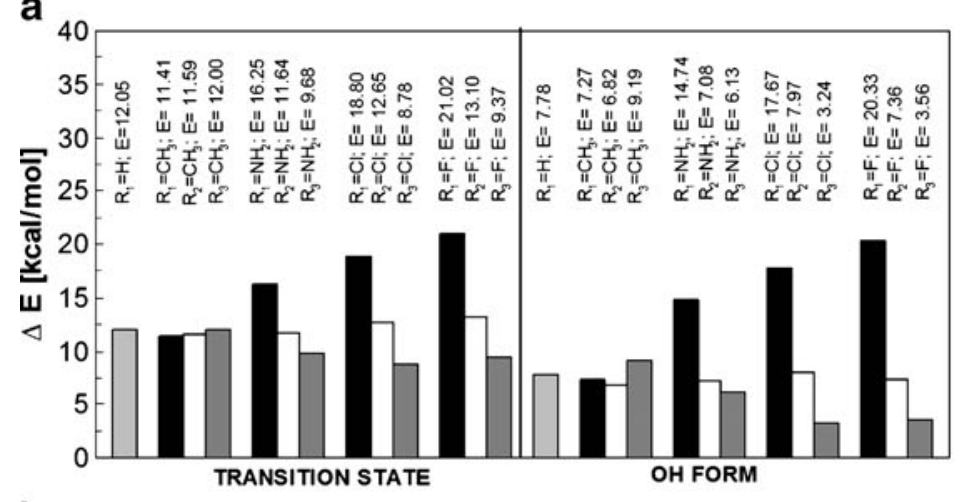<smiles>[R]c1[o+]n(C)c([R3])c1[R]</smiles>

b

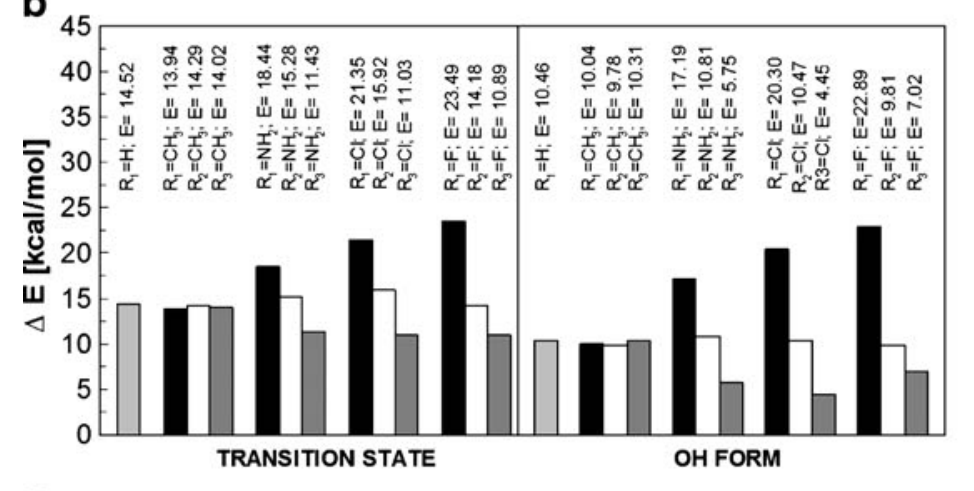<smiles>[R]C1=[O+]CNC([R3])=C1[R2]</smiles>

c

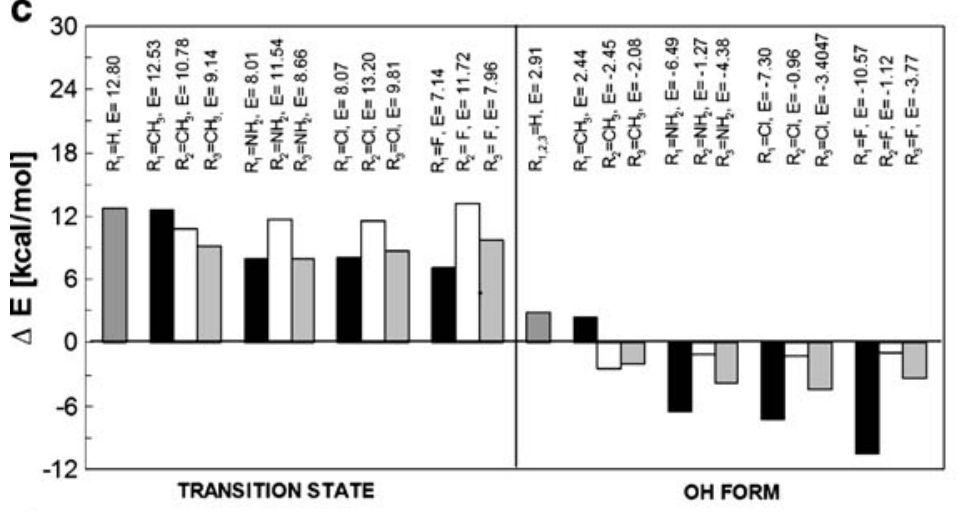<smiles></smiles>

\section{d}

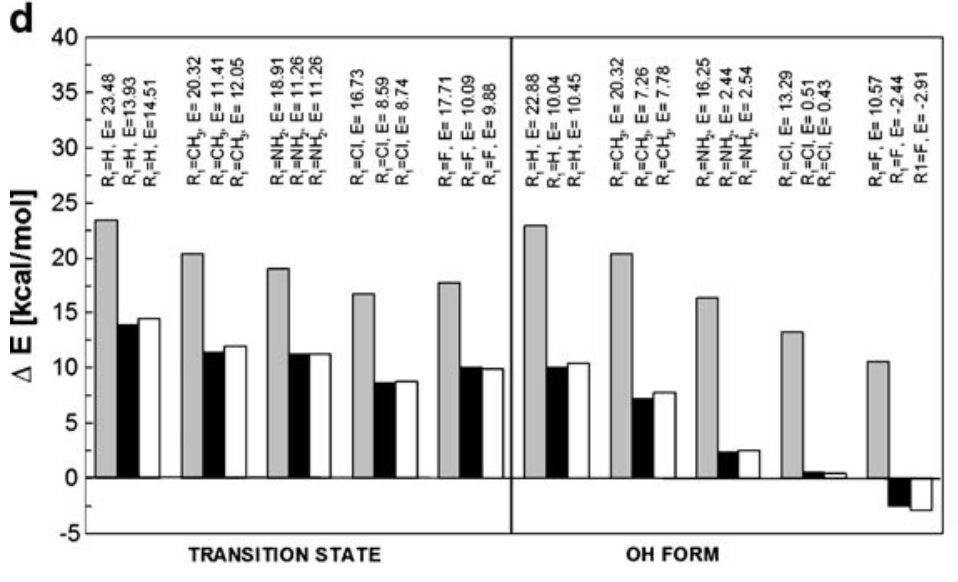<smiles>[R]C1=CO[CH]N([R2])C1[R3]</smiles> 
Fig. 2 Correlations between the electron density (a) at the $\mathrm{OH}$ bond critical point $\left(\rho_{\mathrm{BCP}}(\mathrm{OH})\right.$, a.u.) and $\mathrm{OH}$ bond length (d $(\mathrm{OH}), \AA)$, and (b) at the $\mathrm{HN}$ bond critical point $\left(\rho_{\mathrm{BCP}}(\mathrm{HN})\right.$, a.u.) and $\mathrm{HN}$ bond length (d $(\mathrm{HN}), \AA)$. Circles, squares and triangles correspond to the $\mathrm{OH}$, transition state and $\mathrm{HN}$ forms, respectively

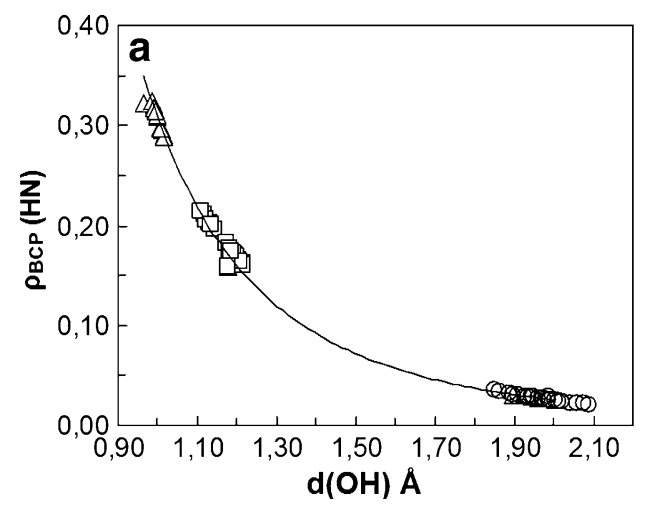

position (Fig. 1a and b) which reveals the decrease of the $\Delta \mathrm{E}_{\mathrm{TS}}$ and $\Delta \mathrm{E}_{\mathrm{OH}}$ values under the $\sigma_{\mathrm{F}}$ constants increase. These trends originate in the following phenomena: 1) the substitution $\left(\mathrm{R}_{1}\right)$ in the $\alpha$ position greatly affects the $\mathrm{C}=\mathrm{O}$ group by weakening its basicity, consequently, it attenuates the hydrogen bond strength and enhances the $\Delta \mathrm{E}_{\mathrm{TS}}$ and $\Delta \mathrm{E}_{\mathrm{HN}-\mathrm{OH}}$ barriers according to the $\mathrm{CH}_{3}, \mathrm{H}, \mathrm{NH}_{2}, \mathrm{Cl}$ and $\mathrm{F}$ sequence; 2$)$ the substitution $\left(\mathrm{R}_{3}\right)$ in the $\gamma$ position mostly influences the amine group by increasing its acidity according to the $\mathrm{Cl}, \mathrm{F}, \mathrm{NH}_{2}$ and $\mathrm{H} \cong \mathrm{CH}_{3}$ sequence. Some exception from the expected $\mathrm{CH}_{3}, \mathrm{H}, \mathrm{NH}_{2}, \mathrm{Cl}$ and $\mathrm{F}$ sequence is observed for the fluoro-substituent $\left(\mathrm{R}_{3}\right)$ in the $\gamma$ position. The reason for this disagreement is a marked polarizability effect of the fluorine atom $(\sigma \alpha=-0.25$ [59]) which causes some attenuation of the acidity of the HN group and the intramolecular hydrogen bonding. Remarkably, the substituent $\left(\mathrm{R}_{2}\right)$ in the $\beta$-position influences but to a lesser extent the $\Delta \mathrm{E}_{\mathrm{TS}}$ and $\Delta \mathrm{E}_{\mathrm{OH}}$ values due to its remote position from the acidic $\left(\mathrm{NR}_{4}\right)$ and basic $(\mathrm{O}=\mathrm{C})$ moieties.

The picture changes for the N-F derivatives $\left(\mathrm{R}_{4}\right)$. The majority of these derivatives is characterized by the $\mathrm{OH}$ tautomeric form prevailing over the $\mathrm{HN}$ tautomeric form (Fig. 1c). The development of the electron acceptor ability of the $R_{1}$ substituent (under weak basicity of the nitrogen atom, at N-F substituent) brings about both the decrease of the $\Delta \mathrm{E}_{\mathrm{TS}}$ values and the strengthening of the $\mathrm{OH}$ tautomeric form prevailing. However, the increase of the electron acceptor properties of the substituent $\left(\mathrm{R}_{2}\right)$ in the $\beta$ position is accompanied by the growth of the $\Delta \mathrm{E}_{\mathrm{TS}}$ values and the weakening of the $\mathrm{OH}$ tautomeric form prevailing.

With respect to the substituent impact on the nitrogen atom $\left(\mathrm{R}_{4}\right)$, the $\Delta \mathrm{E}_{\mathrm{TS}}$ and $\Delta \mathrm{E}_{\mathrm{OH}}$ values are getting smaller according to the $\mathrm{H}, \mathrm{CH}_{3}, \mathrm{NH}_{2}, \mathrm{Cl}$ and $\mathrm{F}$ sequence (Fig. 1d). Some discrepancy as to the expected $\mathrm{CH}_{3}, \mathrm{H}, \mathrm{NH}_{2}, \mathrm{Cl}$ and F sequence is observed for the $\mathrm{H}$ substituent which slightly influences the acidity of the amine group. A similar deviation was discovered for ortho-hydroxy aryl Schiff bases and explained by a significant polarization effect of the NH group [41, 60, 61].

In terms of the structural data of the hydrogen bridge $(\mathrm{d}(\mathrm{OH}), \mathrm{d}(\mathrm{HN})$ and $\mathrm{d}(\mathrm{OH}))$, they are characterized by the following tendencies: 1) the elongation of the $\mathrm{HN}$ bond results in the reduction of the hydrogen bond and the $\mathrm{OH}$ bond lengths; 2) the elongation of the $\mathrm{OH}$ bond also triggers the reduction of the hydrogen bond and the $\mathrm{HN}$ bond lengths; 3 ) the shortest hydrogen bridge is found for the transition state; 4) the position of the TS is more shifted toward the reagents $\left(\mathrm{d}(\mathrm{O}-\mathrm{H})_{\mathrm{TS}}<\mathrm{d}(\mathrm{N}-\mathrm{H})_{\mathrm{TS}}\right.$ for prevailing of the $\mathrm{NH}^{\cdots} \mathrm{O}$ form) according to Leffler-Hammond rule [62, 63].
Fig. 3 Correlations between electron density at the chelate chain critical points $\left(\rho_{\mathrm{RCP}}(\mathrm{ch})\right.$, a.u.) and (a) $\mathrm{OH}$ bond length $(\mathrm{d}$ $(\mathrm{OH}), \AA)$, and (b) the electron density at the $\mathrm{OH}$ bond critical point $\left(\rho_{\mathrm{BCP}}(\mathrm{OH})\right.$, a.u. $)$
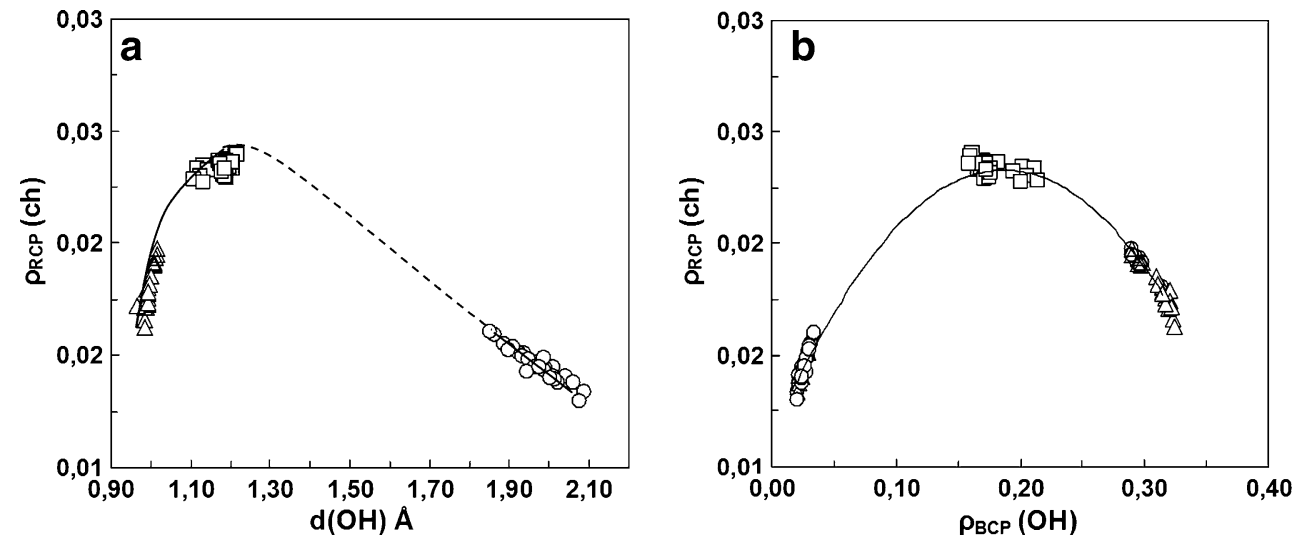


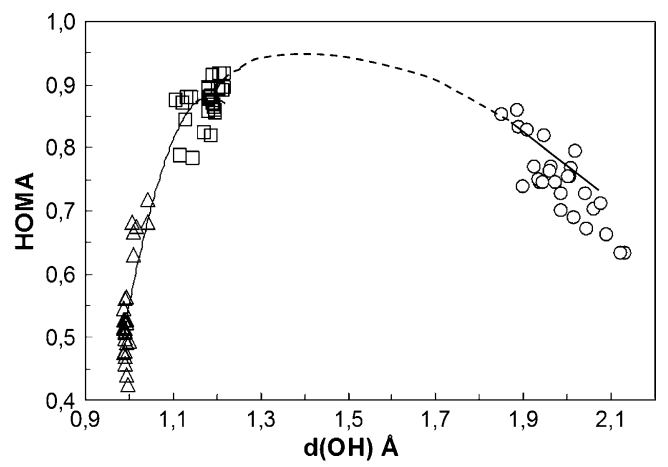

Fig. 4 Scatter plot of the chelate chain aromaticity index HOMA(ch) versus the $\mathrm{OH}$ bond length $(\mathrm{d}(\mathrm{OH}), \AA)$

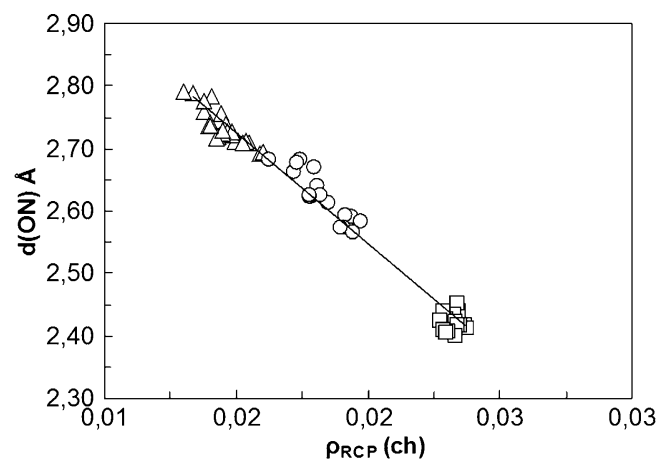

Fig. 5 Correlations between hydrogen bond length $(\mathrm{d}(\mathrm{ON}), \AA)$ and electron density at chelate chain critical points $\left(\rho_{\mathrm{RCP}}(\mathrm{ch})\right.$, a.u. $)$
Analysis of aromatic and AIM parameters vs. tautomeric equilibrium

To verify the calculations obtained by the QTAIM method the $\rho_{\mathrm{BCP}}(\mathrm{XH})=\mathrm{f}(\mathrm{d}(\mathrm{XH}))(\mathrm{X}=\mathrm{N}$ or $\mathrm{O}$ atom $)$ dependence was developed (Fig. 2; $\rho_{\mathrm{BCP}}(\mathrm{OH})=0.3489 \times(\mathrm{OH})^{-3,522}, \mathrm{R}^{2}=$ $\left.0.9991 ; \rho_{\mathrm{BCP}}(\mathrm{NH})=0.3071 \times(\mathrm{NH})^{-3,5938}, \mathrm{R}^{2}=0.9987\right)$. The dependence taken by means of full optimization for different substituents in $\alpha-\gamma$ positions appears to be an exponential curve which is in accordance with the results obtained by non-adiabatic approach $[41,64]$. Remarkably, the results for different substituents under full optimization are in agreement with those found under non-adiabatic approach for ortho-hydroxy aryl Schiff bases [65].

The next stage of the study was to verify the $\rho_{\mathrm{RCP}}(\mathrm{ch})=\mathrm{f}$ $(\mathrm{d}(\mathrm{OH}))$ and $\rho_{\mathrm{RCP}}(\mathrm{ch})=\mathrm{f}\left(\rho_{\mathrm{BCP}}(\mathrm{OH})\right)$ dependencies (Fig. 3) calculated for the $\mathrm{OH}$, TS and HN states of the compounds. These dependencies look like Morse or bell-shaped curves. A similar shape of the curve is traced for $\operatorname{HOMA}(\mathrm{ch})=\mathrm{f}(\mathrm{d}$ $(\mathrm{OH})$ ) scatter plot (Fig. 4). The calculated scatter plot conditioned by some scattering of points supports the trends which are not observed under non-adiabatic approach [66]. The correlations reveal that the maximum of the electronic density at quasi-aromatic critical point $\left(\rho_{\mathrm{RCP}}(\mathrm{ch})\right)$ and maximum aromaticity reaches its top in the transition state. This result comes in agreement with the results obtained in paper 66, where the comparison of the aromaticity of hydrogen-bonded and Li bonded aryl Schiff bases derivatives was carried out.
Fig. 6 Correlations between hydrogen bond length $(\mathrm{d}(\mathrm{ON}), \AA)$ and electron density at (a) chelate chain critical points $\left(\rho_{\mathrm{RCP}}(\mathrm{ch})\right.$, a.u. $)$, and (b) the $\mathrm{HN}$ bond length $(\mathrm{d}(\mathrm{HN}), \AA)$
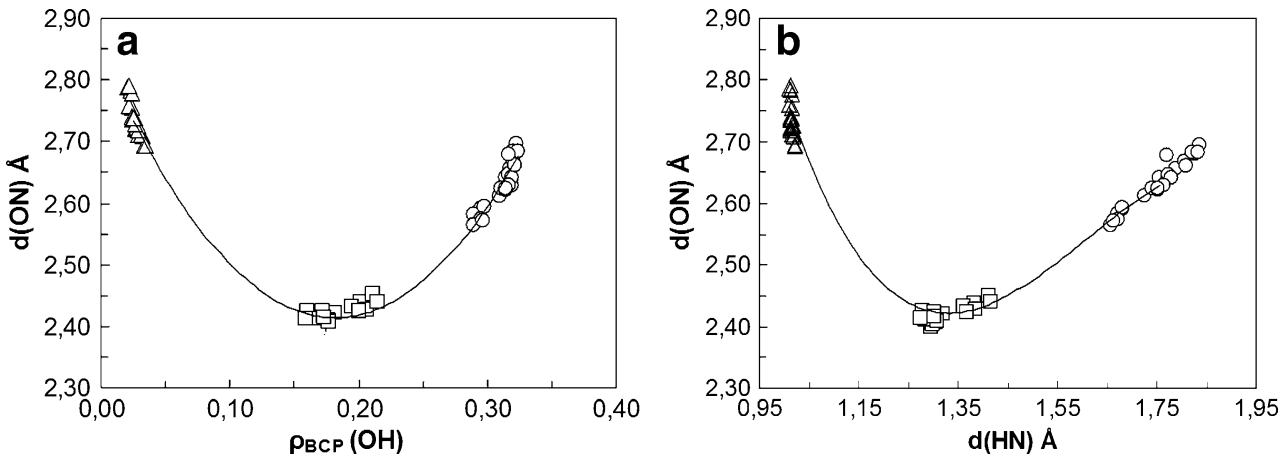

Scheme 3 Structural and electron-topological scheme of the tautomeric equilibrium

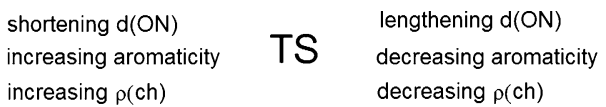

OH FORM

HN FORM

lengthening $d(\mathrm{ON})$ decreasing aromaticity decreasing $\rho(\mathrm{ch})$ shortening $d(O N)$

increasing aromaticity

increasing $\rho(\mathrm{ch})$ 
The $\mathrm{d}(\mathrm{ON})=\mathrm{f}\left(\rho_{\mathrm{RCP}}(\mathrm{ch})\right)$ correlation (Fig. $\left.5 ; \mathrm{d}(\mathrm{ON})\right)=$ $\left.-35.482 \times\left(\rho_{\mathrm{RCP}}(\mathrm{ch})\right)+3.2575, \mathrm{R}^{2}=0.9849\right)$ appears to be one of the most interesting dependencies which states that the shortening of the hydrogen bridge results from the growth of the electron density at the critical point of quasi-aromatic formation. But comparatively, the parabolic dependence $\mathrm{d}(\mathrm{ON})=\mathrm{f}\left(\rho_{\mathrm{BCP}}(\mathrm{XH})\right)$ is more informative with respect to tautomeric equilibrium (Fig. 6) in terms of the basic parameter $(\mathrm{d}(\mathrm{ON}))$ describing the hydrogen bond strength.

The $\rho_{\mathrm{RCP}}(\mathrm{ch})=\mathrm{f}(\mathrm{d}(\mathrm{OH})), \quad \rho_{\mathrm{RCP}}(\mathrm{ch})=\mathrm{f}\left(\rho_{\mathrm{BCP}}(\mathrm{OH})\right)$, $\operatorname{HOMA}(\mathrm{ch})=\mathrm{f}(\mathrm{d}(\mathrm{XH}))$ and $\mathrm{d}(\mathrm{ON})=\mathrm{f}\left(\rho_{\mathrm{RCP}}(\mathrm{OH})\right)$ dependencies (Figs. 3, 4 and 5) show that strengthening of the hydrogen bond brings about the increase of both electron density at the critical point of quasi-aromatic formation and the chelate chain aromaticity (Scheme 3).

Bearing in mind the fact of mutual increase of aromaticity and $\pi$-component in the aromatic formation one can confirm that the increase of $\rho_{\mathrm{RCP}}(\mathrm{ch})$ provokes the active participation of $\pi$-component.

\section{Conclusions}

It has been shown that for the $\mathrm{HN}$ tautomeric form the increase of the electron-acceptor ability of the substituents $\left(\mathrm{R}_{1}\right.$ and $\left.\mathrm{R}_{2}\right)$ in $\alpha$ and $\beta$ positions evokes a larger prevailing this form. In case of the $\mathrm{OH}$ tautomeric form the growth of the electron-acceptor ability of the substituents $\left(R_{1}\right)$ in $\beta$ position contributes into the $\mathrm{OH}$ tautomeric form prevailing, whereas for the substituent $\left(\mathrm{R}_{2}\right)$ in $\beta$ position it reveals a reverse trend. With respect to the influence of substituent $\left(\mathrm{R}_{3}\right)$ in the $\gamma$-position for carbonylamines, the growth of the electron-acceptor ability hinders the prevailing of the $\mathrm{HN}$ tautomeric form. However, for the HN tautomeric form the impact of the substituent $\left(\mathrm{R}_{3}\right)$ in $\gamma$-position seems quite complicated due to mutual compensating action of the steric, inductive, resonance and polarizability effects, as well as local $\mathrm{N}-\mathrm{H}^{\cdots} \mathrm{F}$ hydrogen bond influence.

The HOMA $(\mathrm{ch})=\mathrm{f}\left(\mathrm{d}(\mathrm{OH}), \rho_{\mathrm{BCP}}(\mathrm{ch})=\mathrm{f}(\mathrm{d}(\mathrm{OH})), \mathrm{d}(\mathrm{ON})=\right.$ $\mathrm{f}\left(\rho_{\mathrm{BCP}}(\mathrm{ch})\right)$ dependencies have been obtained. The HOMA $(\mathrm{ch})=\mathrm{f}(\mathrm{d}(\mathrm{OH}))$ and $\rho_{\mathrm{BCP}}(\mathrm{ch})=\mathrm{f}(\mathrm{d}(\mathrm{OH}))$ dependencies are bell-shaped and indicate that the transfer process from one tautomeric form to another goes via a transition state. According to these dependencies in the transition state one can observe the maximum delocalization of $\pi$-component of the chelate chain and the maximum electron density of quasi-aromatic formation. The $\mathrm{d}(\mathrm{ON})=\mathrm{f}\left(\rho_{\mathrm{BCP}}(\mathrm{ch})\right)$ dependence states that the electron density at the critical points of quasi-aromatic formation is a measure of the intramolecular hydrogen bond strength. According to the presented dependencies the enhancement of the hydrogen bond strength leads to the growth of $\rho_{\mathrm{BCP}}(\mathrm{ch})$ and HOMA(ch) and reaches its maximum in the transition state. Krygowski et al. [58] stated earlier that the increase of aromaticity strengthens $\pi$-component participation. Therefore, the strengthening of the hydrogen bond in the studied compounds is conditioned by the $\pi$-electron delocalisation in the chelate chain.

Acknowledgments The authors acknowledge the Wrocław Center for Networking and Supercomputing for generous computer time. P.L. acknowledges the Wrocław University of Technology for financial support.

Open Access This article is distributed under the terms of the Creative Commons Attribution Noncommercial License which permits any noncommercial use, distribution, and reproduction in any medium, provided the original author(s) and source are credited.

\section{References}

1. Buemi G, Grabowski SJ (Eds) (2006) The hydrogen bonding-new insights. Springer, Berlin, pp 51-107

2. Raczyńska ED, Kosińska W, Ośmiałowski B, Gawinecki (2005) Chem Rev 105:3561-3612

3. Grabowski SJ, Leszczynski J (eds) (2006) The hydrogen bonding - new insights, Springer, Berlin, pp 487-512

4. Gilli G, Gilli P (2009) The Nature of the Hydrogen Bond. Oxford University Press

5. Sanz P, Mó O, Yanez M, Elguero J (2008) Chem Eur J 14:42254232

6. Sanz P, Mó O, Yanez M, Elguero J (2009) Phys Chem Chem Phys 11:762-769

7. Filarowski A, Koll A, Sobczyk L (2009) Curr Org Chem 13:172193, and references cited herein

8. Nedeltcheva D, Antonov L, Lycka A, Damyanova B, Popov S (2009) Curr Org Chem 13:217-239, and references cited herein

9. Sheikhshoaie I, Fabian WMF (2009) Curr Org Chem 13:149-171, and references cited herein

10. Buemi G, Zuccarello F, Venuvanalingam $P$, Ramalingam $M$ (2000) Theor Chem Acc 104:226-234

11. Musin RN, Mariam YH (2006) J Phys Org Chem 19:425-444

12. Bouchy A, Rinaldi D, Rivail J-L (2004) Int J Quantum Chem 96:237-281

13. Lenain P, Mandado M, Mosquera RA, Bultinck P (2008) J Phys Chem A 112:10689-10696

14. Raissi H, Moshfeghi E, Jalbout AF, Hosseini MS, Fazli M (2007) Int J Quantum Chem 107:1835-1845

15. Kania L, Kamieńska-Trela K, Witkowski M (1983) J Mol Struct 102:1-17

16. Dąbrowski J, Kamieńska-Trela K (1976) J Am Chem Soc 98:2826-2834

17. Dąbrowski J, Kamieńska-Trela K, Kania L (1976) Tetrahedron 32:1025-1029

18. Dudek GO, Holm RH (1962) J Am Chem Soc 84:2691-2696

19. Dudek GO, Dudek EP (1966) J Am Chem Soc 88:2407-2412

20. Tayyari SF, Raissi H, Tayyari F (2002) Spectrochim Acta A 58:1681-1695

21. Dudek GO, Holm RH (1961) J Am Chem Soc 83:2099-2104

22. Brown NMD, Nouhebal DC (1968) Tetrahedron 24:5655-5664

23. Martin R-F, Jamsosis GA, Martin BB (1961) J Am Chem Soc 83:73-75

24. Rybarczyk-Pirek AJ, Grabowski SJ, Malecka M, Nawrot-Modranka J (2002) J Phys Chem A 106:11956-11962

25. Nowroozi AR, Raissi H, Farzad F (2005) J Mol Struct THEOCHEM 730:161-169 
26. Raczyńska ED (2005) Pol J Chem 79:1003-1006

27. Krygowski TM, Wozniak K, Anulewicz R, Pawlak D, Kolodziejski W, Grech E, Szady A (1997) J Phys Chem 101:9399-9404

28. Filarowski A, Koll A, Głowiak T, Majewski E, Dziembowska T (1998) Ber Bunsenges Phys Chem 102:393-402

29. Filarowski A, Koll A, Głowiak T (2002) J Mol Struct 615:97-108

30. Filarowski A, Kochel A, Cieślik K, Koll A (2005) J Phys Org Chem 18:986-993

31. Raczynska ED, Krygowski TM, Zachara JE, Osmialowski B, Gawinecki R (2005) J Phys Org Chem 18:892-897

32. Grabowski SJ, Sokalski WA, Leszczynski J (2006) J Phys Chem A 110:4772-4779

33. Grabowski SJ, Sokalski WA, Dyguta E, Leszczynski J (2006) J Phys Chem B 110:6444-6446

34. Palusiak M, Simon S, Sola M (2006) J Org Chem 110:5875-5822

35. Palusiak M, Krygowski TM (2007) Chem Eur Chem 13:79968006

36. Zubatyuk RI, Volovenko YM, Shishkin OV, Gorb L, Leszczynski J (2007) J Org Chem 72:725-735

37. Filarowski A, Kochel A, Kluba M, Kamounah F (2008) J Phys Org Chem 21:939-944

38. Kluba M, Lipkowski P, Filarowski A (2008) Chem Phys Lett 463:426-430

39. Karabiyik H, Petek H, Iskeleli NO, Albayrak C (2009) Struct Chem 20:903-910

40. Karabiyik H, Petek H, Iskeleli NO, Albayrak C (2009) Struct Chem 20:1055-1065

41. Filarowski A, Majerz I (2008) J Phys Chem 112:3119-3126

42. Krygowski TM (1993) J Chem Inf Comput Sci 33:70-78

43. Bader RF (1990) Atoms in molecules: a quantum theory. Oxford University Press, New York

44. Koch U, Popelier PL (1995) J Phys Chem 99:9747-9754

45. Krygowski TM, Cyrański MK (2001) Chem Rev 101:1385-1420

46. Sobczyk L, Grabowski SJ, Krygowski TM (2005) Chem Rev $105: 3513-3560$

47. Filarowski A, Kochel A, Cieslik K, Koll A (2005) J Phys Org Chem 18:986-993

48. Raczyńska ED, Krygowski TM, Zachara JE, Ośmiałowski B (2005) J Phys Org Chem 18:892-897

49. Korth H-G, de Heer MI, Mulder R (2002) J Phys Chem A 106:8776-8789
50. Krygowski TM, Zachara JE, Szatylowicz H (2005) J Phys Org Chem 18:110-114, and references cited herein

51. Frisch MJ, Trucks GW, Schlegel HB, Scuseria GE, Robb MA, Cheeseman JR, Montgomery JA, Vreven T, Kudin KN, Burant JC, Millam JM, Iyengar SS, Tomasi J, Barone V, Mennucci B, Cossi M, Scalmani G, Rega N, Petersson GA, Nakatsuji H, Hada M, Ehara M, Toyota K, Fukuda R, Hasegawa J, Ishida M, Nakajima T, Honda Y, Kitao O, Nakai H, Klene M, Li X, Knox JE, Hratchian HP, Cross JB, Bakken V, Adamo C, Jaramillo J, Gomperts R, Stratmann RE, Yazyev O, Austin AJ, Cammi R, Pomelli C, Ochterski JW, Ayala PY, Morokuma K, Voth GA, Salvador P, Dannenberg JJ, Zakrzewski VG, Dapprich S, Daniels AD, Strain MC, Farkas O, Malick DK, Rabuck AD, Raghavachari K, Foresman JB, Ortiz JV, Cui Q, Baboul AG, Clifford S, Cioslowski J, Stefanov BB, Lui G, Liashenko A, Piskosz P, Komaromi I, Martin RL, Fox DJ, Keith T, Al-Laham MA, Peng CY, Nanayakkara A, Challacombe M, Gill PMW, Johnson B, Chen W, Wong MW, Gonzalez C, Pople JA (2004) Gaussian 03, Revision B.03. Gaussian Inc, Wallingford, CT

52. McLean AD, Chandler GS (1980) J Chem Phys 72:5639-5648

53. Krishnan R, Binkley JS, Seeger R, Pople JA (1980) J Chem Phys 72:650-654

54. Clark T, Chandrasekhar J, Spitznagel GW, Schleyer PvR (1983) J Comput Chem 4:294-301

55. Frisch MJ, Pople JA, Binkley JS (1984) J Chem Phys 80:3265-3269

56. Møller C, Plesset MS (1934) Phys Rev 46:618-622

57. Biegler-König J, Schönbohm D, Bayles D (2001) J Comput Chem 22:545-559

58. Krygowski TM, Cyranski M, Czarnoski Z, Hafelinger G, Katritzky A (2000) Tetrahedron 56:1783-1796

59. Hansch C, Leo A, Taft RW (1991) Chem Rev 91:165-195

60. Fores M, Duran M, Sola M (2000) Chem Phys 260:53-64

61. Palomar J, De Paz JLG, Catalan J (2000) J Phys Chem A 104:6453-6463

62. Leffler JE (1953) Science 117:340-341

63. Hammond GS (1955) J Am Chem Soc 77:334-338

64. Espinosa E, Alkorta I, Elguero J, Molins E (2002) J Chem Phys 117:5529-5542

65. Filarowski A, Majerz I, Martyniak A (2010) J Phys Chem A in preparation

66. Krygowski TM, Zachara-Horeglad JE, Palusiak M (2010) J Org Chem 75:4944-4949 